\title{
Histamine containing endocrine cells in the human stomach
}

\author{
H Lönroth, R Håkanson, L Lundell, F Sundler
}

\begin{abstract}
Histamine and chromogranin A-immunoreactive cells were studied in the mucosa of the human stomach. Cells reacting to both histamine and chromogranin A-antibodies (histamine containing endocrine cells), were demonstrated by double immunostaining and found to be restricted to the oxyntic mucosa. Histamine containing cells that did not stain with chromogranin $\mathbf{A}$-antibodies were numerous throughout the stomach. Of the histamine immunoreactive cells in the oxyntic gland area $22 \%$ reacted with antibodies against chromogranin A. Histamine containing endocrine cells constituted $44 \%$ of the total number of endocrine cells in the oxyntic mucosa. These findings suggest that the histamine containing endocrine cells in the human stomach are identical with the so called enterochromaffin like cells.
\end{abstract}

Gastric mucosal histamine is likely to be involved in the control of gastric acid secretion. The inhibition of basal as well as stimulated acid secretion by $\mathrm{H}_{2}$-receptor blockers' strongly supports this view. Favourable evidence of a physiological role of histamine in the activation of the parietal cell has come from experiments in rats, where most of the mucosal histamine is stored in a population of endocrine cells, the so called enterochromaffin like (ECL) cells. ${ }^{2}$ These cells occur basally in the glands at some distance from the main population of parietal cells. In the early days OPT-histofluorescence was used to show histamine..$^{3-5}$ In more recent years immonocytochemical methods have been developed for the demonstration of this compound. ${ }^{67}$ There is little doubt that immunocytochemistry is superior to OPT-histofluorescence with respect to specificity and sensitivity. This is shown by the failure of OPT to demonstrate histamine in neurones in the hypothalamus and in endocrine cells in the stomach of for instance the guinea pig and the rabbit. In these species histamine antibodies have shown a moderate number of histamine immunoreactive endocrine cells basally in the oxyntic glands.

In the human stomach, histamine mainly occurs in the numerous mucosal mast cells. ${ }^{8}$ The presence of relatively few histamine containing endocrine like cells in the oxyntic mucosa of the human stomach was recently shown by histamine immunostaining.?

The aim of the present study was to answer the following questions: (i) in which cells is histamine stored in the mucosa of the human stomach? and (ii) Are there regional and topographical differences regarding the cellular localisation of histamine within the human stomach?

\section{Methods}

BIOPSY COLLECTION

Healthy volunteers (four women, eight men, mean age 43 years) were investigated. Endoscopy was carried out between eight and 12 am after an overnight fast. No premedication was used, except for local anaesthesia (Xylocaine ${ }^{(\mathbb{R})}$ ) applied to the posterior pharynx. During oesophagogastroduodenoscopy gastric mucosal biopsies were obtained from different sites as shown in Figure 1. After entry of the endoscope into the stomach the macroscopic border at the major curvature separating the oxyntic and antral gland area was located both with the stomach exsufflated and maximally insufflated with air. The endoscope was thereafter retracted 4-5 $\mathrm{cm}$ and biopsies were taken from that site. The endoscope was then rotated 3-4 cm towards the anterior and posterior wall of the stomach respectively and biopsies collected. Antral biopsies were obtained at the major curvature 3-4 cm aboral to the pyloric sphincter. The endoscopes used were Olympus XQ or XQ10 with standard biopsy forceps FB $24 \mathrm{~K}$. Two biopsies from each site were taken and immediately frozen in a mixture of propane and propylene at the temperature of liquid nitrogen and stored at $-70^{\circ} \mathrm{C}$ until further processing.

ANTIBODIES

Histamine antiserum (code no. 8431, Milab, Malmö, Sweden) was raised in rabbits using

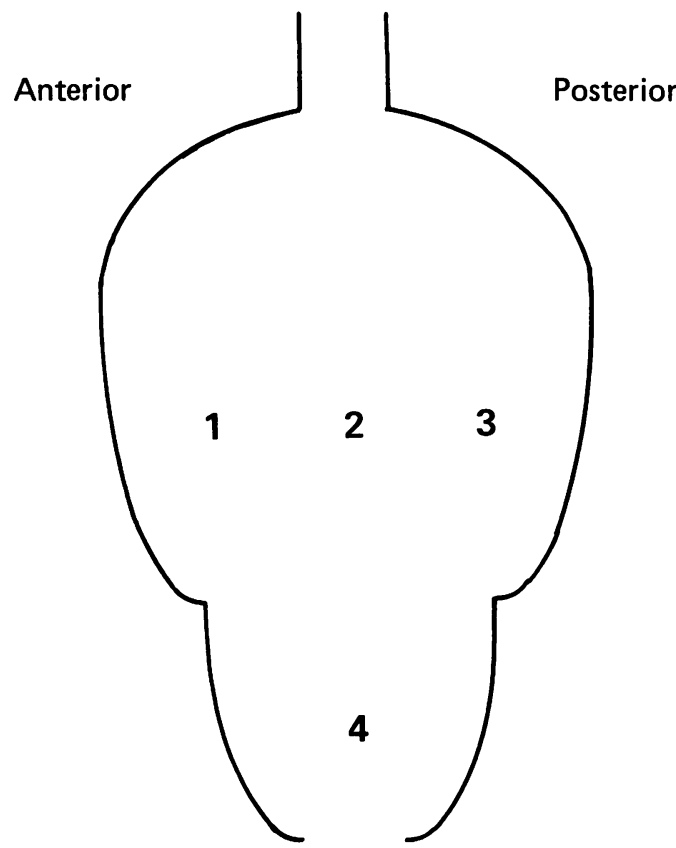

Figure 1: Schematic drawing of the stomach, cut open along the minor curvature, showing four different biopsy sites.
Department of Medical Cell Research, University F Sundler

Correspondence to: $\mathrm{H}$ Lönroth, Department of Surgery, Sahlgren's Hospital Sweden.

Accepted for publication 10 July 1989 
histamine coupled to serum albumin (for details see 7) and used in dilution 1:1280.

CHROMOGRANIN ANTIBODIES

Peptide hormone producing endocrine cells were shown collectively by the use of an antiserum to provided by Dr D T O'Connor, V A Center, La Jolla, Ca, USA). Chromogranin A antisera are known to stain the vast majority, if not all, endocrine cell types in the mammalian oxyntic mucosa. ${ }^{9}$ For detection of histamine containing immunostaining with histamine antibodies and a monoclonal antibody against chromogranin $\mathrm{A}$ (code LK2H10, Hybritech, San Diego, Ca, USA) diluted 1:80 from stock solution. This antibody recognises human chromogranin A. ${ }^{9}$

GASTRIN ANTISER UM

Gastrin cells were shown using an antiserum raised against gastrin-17 (code no 7835, MILAB, Malmö, Sweden) and used in dilution 1:320.

5-HYDROXYTRYPTAMINE ANTISERUM Enterochromaffin (EC) cells were demonstrated by virtue of their 5-hydroxytryptamine content ${ }^{10}$ using a rabbit antiserum raised against protein conjugated 5-hydroxytryptamine.

SOMATOSTATIN ANTIBODIES

Somatostatin cells were shown using monoclonal somatostatin antibodies (Nova Research, Bagsvaerd, Denmark). The antibodies were diluted 1:40 from the stock solution. The frequency of immunoreactive cells was studied chromogranin A (code no 137-1, diluted 1:640; endocrine cells we used simultaneous double

using histamine antiserum, chromogranin A antiserum 137-1 and gastrin antiserum. In one experiment we subjected three consecutive plastic sections of oxyntic mucosa to immunostaining for somatostatin, histamine and 5 hydroxytryptamine, respectively. This was performed in order to examine whether the histamine-immunoreactive cells stored also somatostatin or 5-hydroxytryptamine.

TISSUE PROCESSING

The biopsies were processed as follows: After freeze drying, the specimens were vapour fixed in diethylpyrocarbonate (DEPC)" and embedded in paraffin or Araldite. Sections were cut at 6-8 $\mu \mathrm{m}$ (paraffin) or $1 \mu \mathrm{m}$ (Araldite) thickness, placed on slides, deparaffinised in xylene and rehydrated. For the demonstration of histamine, chromogranin A and gastrin, respectively, the sections were subjected to the indirect immunofluorescence procedure. ${ }^{12}$ All antibodies were diluted in phosphate buffered saline and applied to the sections at $4^{\circ} \mathrm{C}$ overnight. Simultaneous double immunostaining was performed by applying monoclonal chromogranin $\mathrm{A}$ antibodies followed by fluorescein isothiocyanate (FITC)-labelled second antibodies and histamine antiserum followed by tetramethylrhodamine isothiocyanate (TRITC) - labelled second antibodies. Selective visualisation of FITC and TRITC was secured by shifting filter settings in the microscope (Zeiss no. 09 for FITC and 15 for TRITC)

The sections were cut perpendicular to the mucosal surface and care was taken to include only specimens that covered the entire depth of the mucosa. In a few cases the biopsies had to be reorientated before appropriate sections could be obtained. The frequency of stained cells was

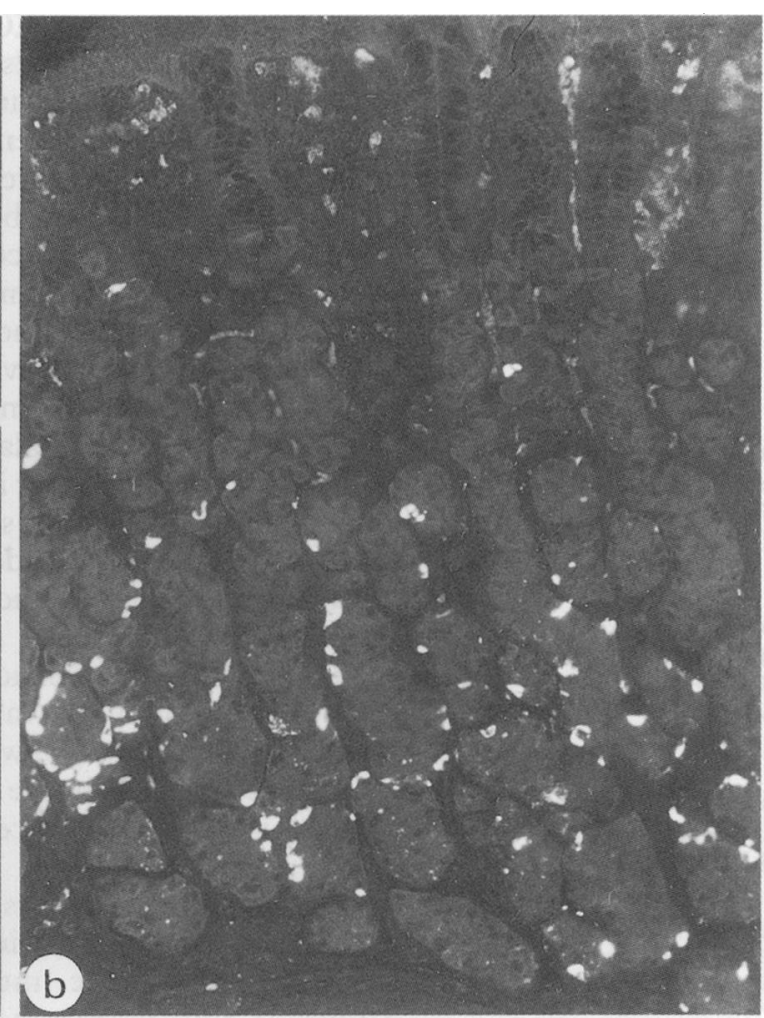

Figure 2: Sections from human oxyntic mucosa $(a)$ immunostained for histamine showing numerous immunoflurescent cells scattered throughout the mucosa; and $(b)$ immunostained for chromogranin A. The chromogranin A-immunofluorescent cells predominate in the basal half of the mucosa. 

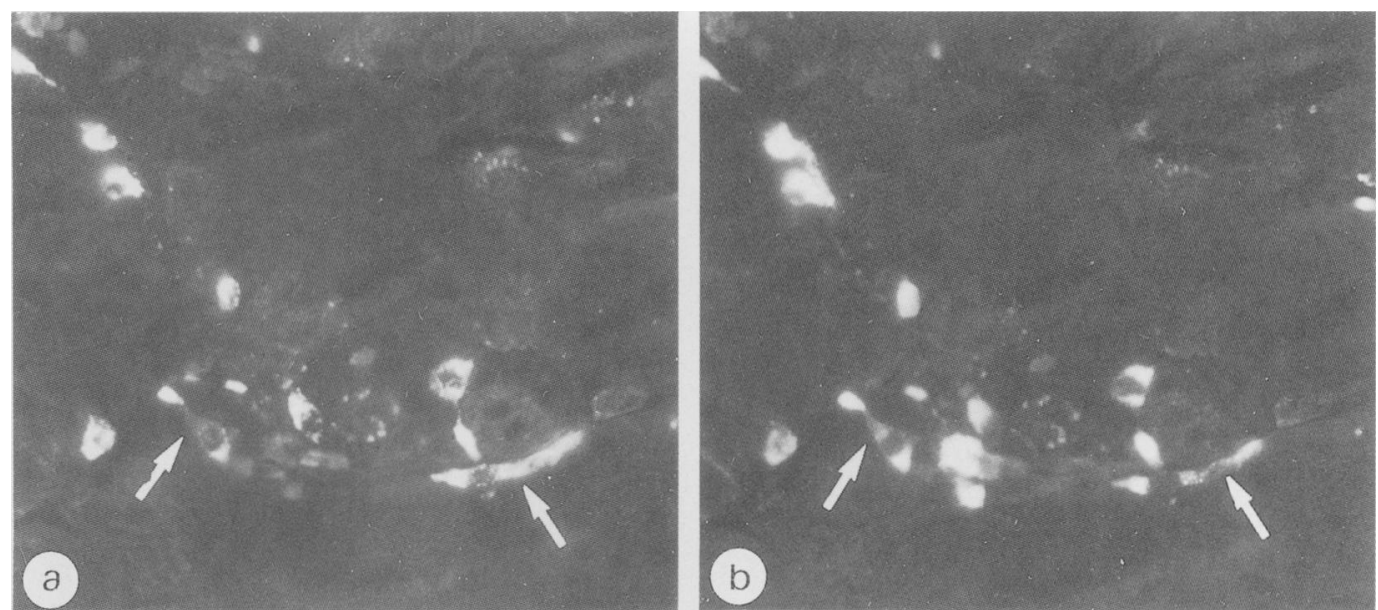

Figure 3: Section from oxyntic mucosa immunostained for chromogranin $A(a)$ and for histamine (b) using a double immunostaining technique with FITC $(a)$ and TRITC $(b)$ as markers. All chromogranin positive cells in this visual field displayed histamine immunofluorescence. Note that some of the histamine and chromogranin reactive cells are elongated and sometimes have long cytoplasmatic processes (arrows).

calculated by counting the number of cells per visual field using $25 \mathrm{x}$ objective and $10 \mathrm{x}$ eyepiece. Cell counts were made on two to four visual fields on one section from each biopsy.

STATISTICAL ANALYSIS AND ETHICS

For the analysis of differences in cell distribution a one factor ANOVA-test for repeated measures was computed. The study was approved by the local ethics committee. Informed consent to participate in the study was obtained from each subject.

\section{Results}

Histamine immunoreactive cells were numerous

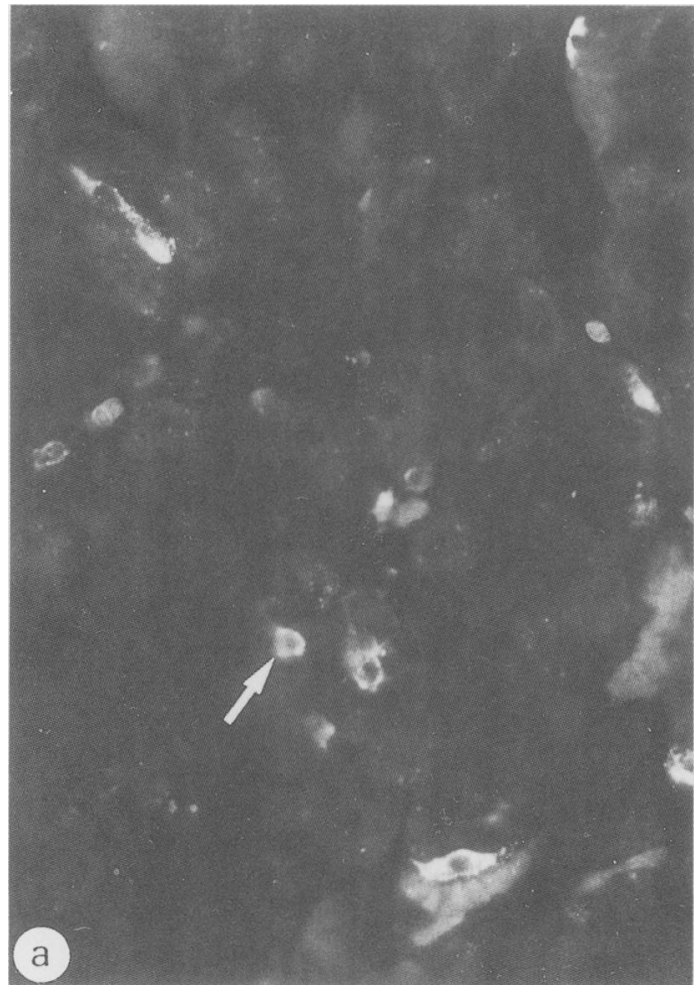

in the oxyntic mucosa, including the lamina propria, and submucosa (Fig 2a). Some of the histamine immunoreactive cells had an epithelial localisation. These cells as a rule displayed a somewhat weaker immunofluorescence than the extraepithelial ones. The histamine immunoreactive cells were often equipped with long cytoplasmic processes. Some of them also looked as if they were tapered on to the oxyntic glands (Figs 3, 4).

In the pyloric gland area histamine immunoreactive cells were found evenly distributed in both mucosal and submucosal layers and situated outside the epithelium (Fig 5).

In the corpus mucosa, cells staining with chromogranin A antibodies predominated in the basal part of the mucosa (Fig 2b). Usually they

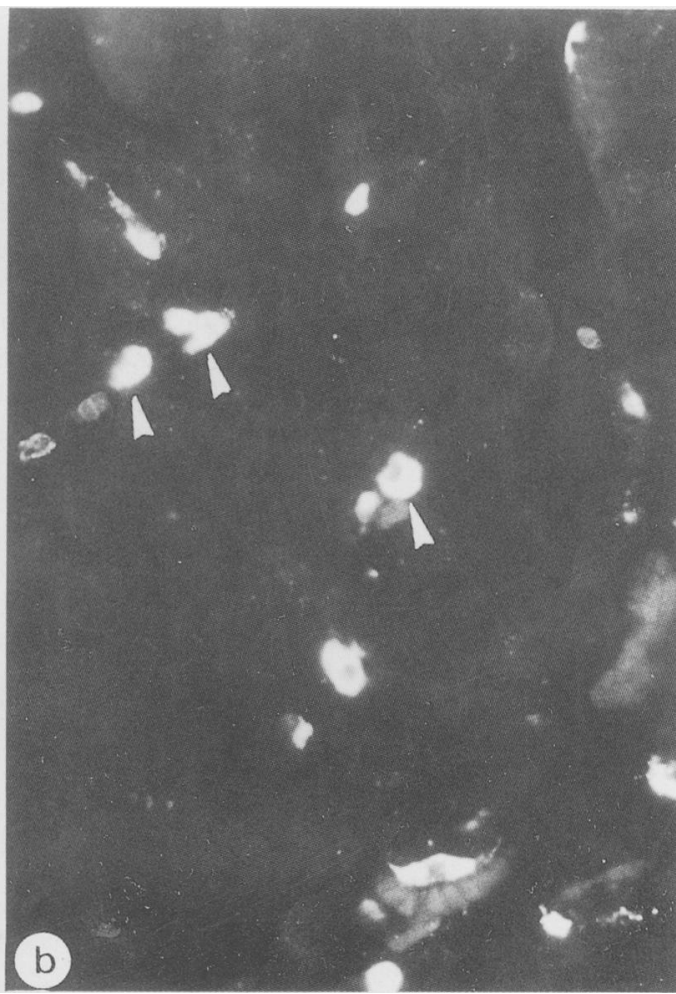

b

Figure 4: Section from the oxyntic mucosa. Double immunostaining for chromogranin A (a) and histamine (b) illustrating that although many of the chromogranin-immunoreactive cells displayed histamine, some of the cells that contained chromogranin $A$ did not store histamine (arrow). Note also that some of the histamine-immunoreactive cells (the most intenselv immunoreactive ones) are not endocrine but presumably mast cells (arrow heads). 


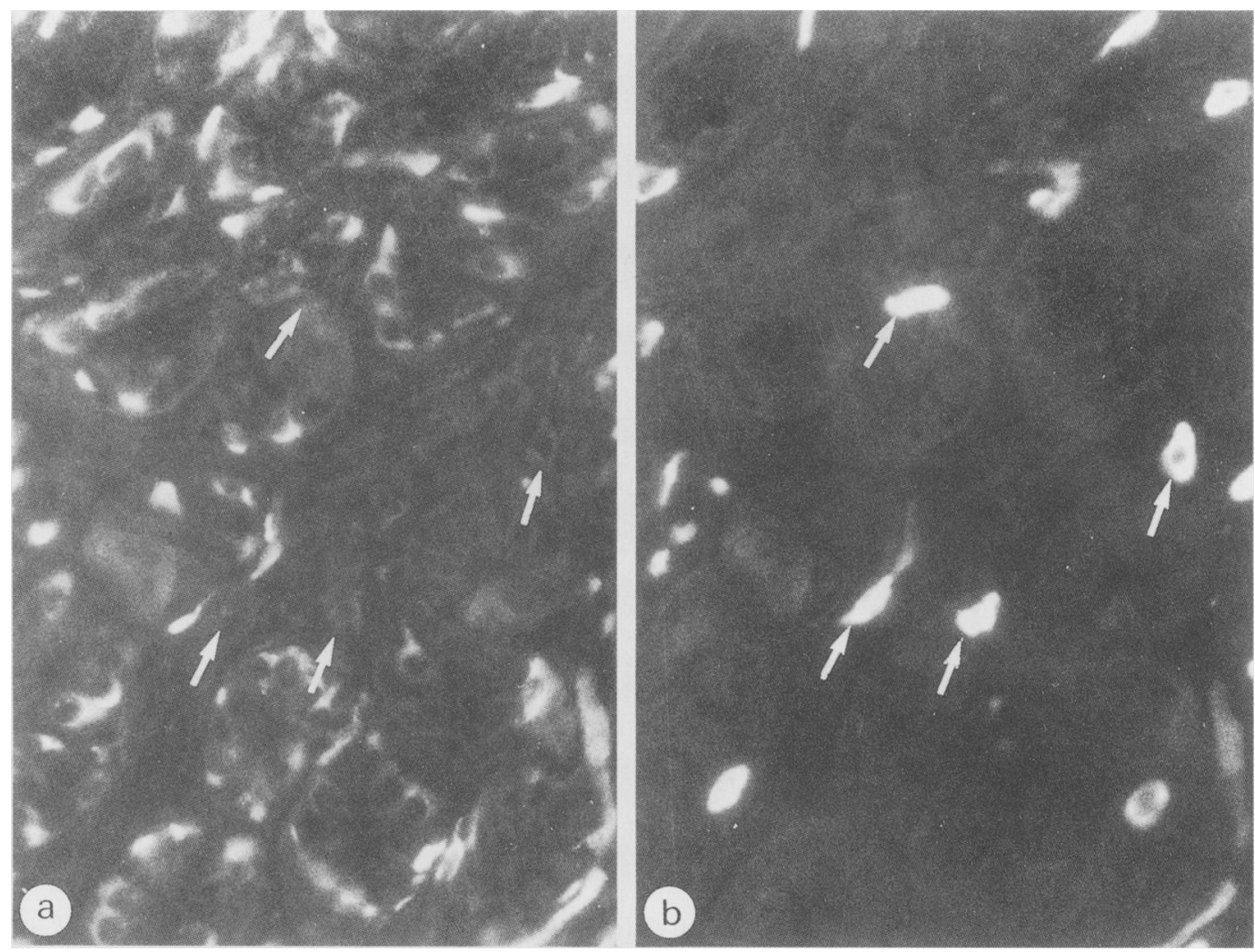

Figure 5: Section from the antral mucosa. Double immunostaining for chromogranin $A(a)$ and histamine $(b) . N u m e r o u s$ chromogranin-immunoreactive cells in the epithelium. The histamine-immunoreactive cells are not identical with the chromogranin A-immunoreactive cells (exemplified by arrows in a and $b$ ).

occurred as single cells, but occasionally clusters of three to four cells were seen. They invariably had an intraepithelial localisation.

In specimens from the antrum, chromogranin A-positive cells occurred predominantly in the basal half of the glands although usually not at the very bottom of the glands.

\section{FREQUENCY OF CELLS}

The frequency of histamine-immunoreactive cells is shown in Figure 6. There was no difference in cell counts between antral and oxyntic mucosa. Within the corpus mucosa (biopsy site $1,2,3$, ) almost identical numbers of histamine containing cells were found.

Chromogranin A-positive cells were found both in corpus and antrum (Fig 7). No difference between biopsy sites was observed.

Gastrin immunoreactive cells were not found in biopsies from the corpus but occurred invari-

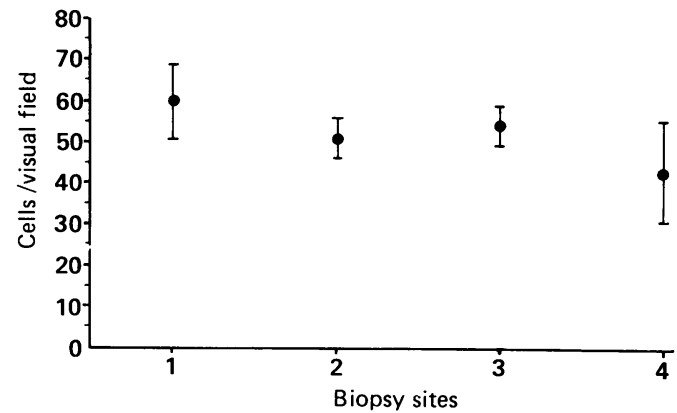

Figure 6: The density of histamine immunoreactive cells in the oxyntic (site 1-3) and antral mucosa (site 4), values expressed as number of cells per visual field. Biopsies were collected from two men and four women. The mean values and standard deviations are given. ably in biopsies from the antral mucosa. They were located within the middle third of the mucosa.

IDENTIFICATION OF HISTAMINE IMMUNOREACTIVE CELLS AS ENDOCRINE CELLS

Cells that contained histamine as well as chromogranin A were identified by the use of double immunostaining. For this purpose we used rabbit antihistamine antiserum (no. 8431) and a monoclonal antichromogranin A antibody (LK2H10) as described above. Histamine was visualised using TRITC labelled second antibody. Chromogranin A was visualised using FITC labelled second antibody. By shifting the filters for FITC and TRITC respectively, TRITC labelled cells appeared throughout the mucosa and submucosa, and FITC labelled cells were seen in the epithelium, basally in the glands (Figs 3, 4). A number of cells emitted both types

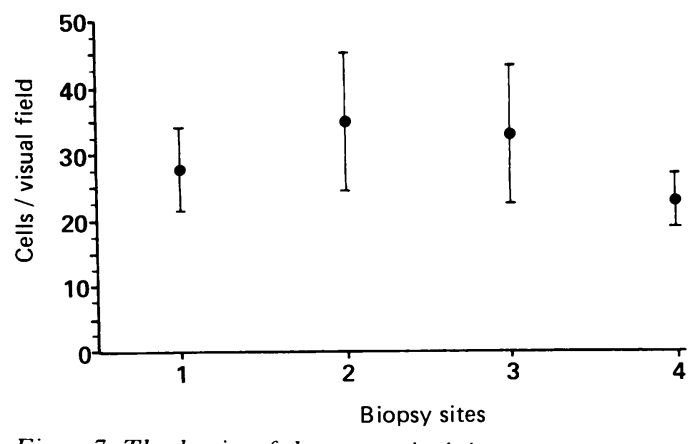

Figure 7: The density of chromogranin A-immunoreactive cells in the oxyntic (site 1-3) and antral mucosa (site 4). Biopsies were collected from two women and five men. The means and standard deviations are given. 
of fluorescence, thus containing both histamine and chromogranin A. These cells, which seemed to lack luminal contact, were classified as histamine containing endocrine cells. In some cells different areas of the cytoplasm displayed immunofluorescence on changing between the two filters, indicating partly different intracellular distribution of histamine and chromogranin A. Although many of the chromogranin immunoreactive cells displayed histamine immunoreactivity, quite a few cells that contained chromogranin did not store histamine (Fig 4). Immunostaining of consecutive plastic sections for somatostatin, histamine and 5hydroxytryptamine, respectively, revealed that the histamine-immunoreactive cells lacked both somatostatin and 5-hydroxytryptamine.

Counts for histamine containing cells, chromogranin A-containing cells and cells containing both histamine and chromogranin $\mathrm{A}$ are illustrated in Figure 8. Forty four per cent of the chromogranin A-positive cells in the oxyntic mucosa contained histamine. Twenty two per cent of histamine-immunoreactive cells in this location reacted with antibodies against chromogranin A. In the antrum mucosa we were unable to show cells containing both histamine and chromogranin A (Figure 5).

The specificity of the chromogranin A immunostaining using the monoclonal antibody was further investigated by double staining with both monoclonal and polyclonal antibodies. The same cells stained with either of the two antibodies.

\section{Discussion}

The human gastric mucosa harbours several endocrine cell types as defined by electron microscopy and histochemistry: ECL, EC, D, A-like (or X), P, $D_{1}$ in the oxyntic mucosa and $\mathrm{G}, \mathrm{EC}$, $\mathrm{D}$, and $\mathrm{P}$ cells in the antrum. ${ }^{1013}$ The EC cells contain 5-hydroxytryptamine but only two of the endocrine cell populations have identified peptide products; $G$ cells store gastrin and $D$ cells store somatostatin. The predominating endocrine cell type of the oxyntic mucosa is the ECL cell. ${ }^{1+}$ So far no peptide hormone has been identified in these cells.

In the rat stomach ECL cells contain large amounts of histamine. ${ }^{3-5}$ Histamine is also found

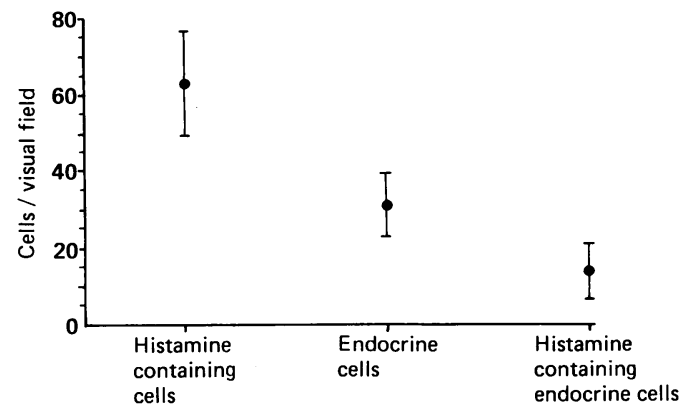

Figure 8: The density of histamine and chromogranin Aimmunoreactive cells in the corpus mucosa. Biopsies were collected from four women and eight men. The bars show the number of histamine immunoreactive cells (histamine containing endocrine cells plus mast cells), chromogranin Aimmunoreactive cells (all endocrine cells) and the number of histamine immunoreactive endocrine cells. Mean values and histamine immunoreactive end
standard deviations are given. in mast cells which are relatively few in this species. There are considerable species differences with respect to histamine immunoreactive cells in the stomach. Histamine immunoreactive endocrine cells are numerous and intensely immunoreactive in the rat stomach but few in dog and man. Mucosal mast cells, on the other hand, are few in the rat stomach but numerous in the canine and human gastric mucosa. Antibodies against chromogranin A demonstrate most, if not all, endocrine cells in the oxyntic mucosa. By applying a double staining technique for chromogranin $\mathrm{A}$ and histamine we were able to show histamine-immunoreactive endocrine cells in the human oxyntic mucosa. These cells, which were clearly distinct from the somatostatin cells and the EC cells, were confined to the basal part of the glands. No such cells could be detected in the antrum. Only non-endocrine histamine containing cells resided in the antral mucosa. Seventy eight per cent of the histamine containing cells of the oxyntic mucosa were of a nonendocrine type. It is most likely that these cells are mast cells, although we experienced unsurmountable difficulties in our attempts to restain specimens prepared for immunohistochemistry with toluidine blue.

The histamine immunoreactive endocrine cells of the oxyntic mucosa constituted $22 \%$ of all histamine immunoreactive cells and about $44 \%$ of all endocrine (chromogranin A-positive) cells in this area. A reasonable assumption is that the histamine and chromogranin A-immunoreactive cells in man are enterochromaffin like (ECL) cells. Our estimate of the number of histaminecontaining endocrine cells in the oxyntic mucosa corresponds fairly well with the estimate of ECL cells obtained by application of a different histochemical technique. Thus, Simonsson and coworkers $^{1+}$ found the ECL cells to represent $35 \%$ of the endocrine cells of the human oxyntic mucosa.

We have found histamine to occur in two separate cell populations in the mucosa of the human stomach. Endocrine cells (probably ECL cells), restricted to the oxyntic gland area, and mastcells, disseminated throughout the wall of the antrum as well as of the body of the stomach.

This study was supported by grants from the Swedish Medical Research Council (projects no. 4499, 1007, 17X-760), the Medical Faculty University of Gothenburg, Tore Nilsson's Foundation and Păhlsson's Foundation.

1 Black JW, Duncan WAN, Durant CJ, Ganellin CR, Parsons ME Definition and antagonism of histamine H2-Receptors. Nature 1972; 236: 385-90.

2 Håkanson R, Larsson LI, Liedberg G, Oscarson J, Sundler F, Vang J. Effects of antrectomy or porta-caval shunting on the histamine-storing endocrine-like cells in oxyntic mucosa of rat stomach. A fluorescence histochemical, electron microscopic and chemical study. F Physiol 1976; 259: 785-800

3 Thunberg R. Localization of cells containing and forming histamine in the gastric mucosa of the rat. Exp Cell Res 1967 47: 108-15.

4 Håkanson R. Owman C. Concomitant histochemical demonstration of histamine and catecholamines in enterochromaffinlike cells of gastric mucosa. Life Sci 1967; 6: 759-66.

5 Ehinger B, Håkanson R, Owman CH, Sporrong B. Histochemical demonstration of histamine in paraffine sections. Biochem Pharmacol 1968; 17: 1997-8.

6 Panula P, Kaartinen M, Mäcklin M, Costa E. Histaminecontaining neuronal and endocrine systems. I Histochem containing neuronal and

7 Håkanson R, Böttcher $\mathrm{G}$, Ekblad $\mathrm{E}$, et al. Histamine in Håkanson R, Böttcher G, Ekblad E, et al. Histamine in 8 Mohri K, Reimann HJ, Lorenz W, Troidl H, Weber D

8 Mohri K, Reimann HJ, Lorenz W, Troidl H, Weber D. duodenal mucosa. Agents Actions 1978; 8: 372-5. 
9 Wilson BS, Lloyd RV. Detection of chromogranin in neuroendocrine cells with a monoclonal antibody. A $m \mathcal{F}$ Pathol 1984 ; 115: $458-68$.

10 Solcia E, Capella C, Vasallo G, Buffa R. Endocrine cells of the gastric mucosa. Int Rev Cvtol 1975; 42: 223-86.

11 Pearse AGE, Polak JM. Bifunctional reagents as vapour- and liquid-phase fixatives for immunohistochemistry. Histochem 7 1975; 7: 179-86.

12 Coons AH, Leduc EH, Conolly JM. Studies on antibody production. I. A method for the demonstration of specific antibody and its application to a study of the hyperimmune antibody and its application to a stud
rabbit. Exp Med 1955; 102: 49-60.
13 Solcia E, Capella C, Buffa R, et al. Cytology of tumours in the gastroenteropancreatic and diffuse (neuro) endocrine system. In: Falkmer S, Hăkanson R, Sundler F, eds. Evolution and tumour pathology of the neuroendocrine sistem. New York: Elsevier Sci Publ B V, 1984; 453-580.

$1+$ Simonsson M, Eriksson S, Hảkanson R, al Fndocrine cells in the human oxyntic mucosa. A histochemical study. Scand 7 Gastroenterol 1988; 23: 1089-99.

15 Nolan JA, Trojanowski JQ, Hogue-Angeletti R. Neurons and neuroendocrine cells contain chromogranin. If Histochem neuroendocrine cells con

For copies of the Final Announcement/Registration Forms, contact:

The World Congresses of Gastroenterology Secretariat P.O. Box 386

St. Leonards, NSW, Australia 2065

Tel. Int. +612-438-4644 Fax Int. +612-439-7546 